\title{
Green patch disease in Iridaea laminarioides (Rhodophyta) caused by Endophyton sp. (Chlorophyta)
}

\author{
Juan A. Correa ${ }^{1}$, Verónica Flores ${ }^{1}$, J. Garrido ${ }^{2}$ \\ ${ }^{1}$ Departamento de Ecología, ${ }^{2}$ Departamento Biología Celular y Molecular, Facultad de Ciencias Biológicas, \\ Pontificia Universidad Católica de Chile, Casilla 114-D, Santiago, Chile
}

\begin{abstract}
A green mottled coloration, or green patch disease, develops in the red alga Iridaea laminarioides Bory when it is infected by the algal endophyte Endophyton sp. The disease is widespread in host populations along the coast of central and southern Chile (33 $17^{\prime} \mathrm{S}$ to $\left.40^{\circ} 33^{\prime} \mathrm{S}\right)$ and affects both gametophytic and sporophytic fronds. It is characterized by green areas, usually located at the base of the thalli, which become soft in texture in fully developed infections. The softening of the host tissue is caused by cellular destruction resulting from endophyte-mediated compaction of the cells, followed by secondary bacterial infections. Bacteria gain access to the host through openings left in the host thallus during spore release from mature sporangia of Endophyton. Both life-history phases of I. laminarioides were successfully infected by unialgal isolates of Endophyton in laboratory trials. Infection was achieved only by germlings from newly settled spores and the process of penetration was completed within 3 d. Softening of laboratory-infected thalli became evident about 8 wk after penetration and thallus destruction was complete after 3 to 4 mo of culture.
\end{abstract}

KEY WORDS: Endophyton sp. - Iridaea laminarioides infections

\section{INTRODUCTION}

Infection by pigmented algal endophytes is a common phenomenon and affects most seaweeds (Goff 1983). It seems apparent that a number of these infections do not have a negative impact upon the host, at least during early stages of colonization by the endophytes. On the other hand, certain endophytic algae have been reported to cause severe changes in their algal hosts, ranging from galls to highly destructive lesions. For example, endophytic members of the brown filamentous genus Streblonema trigger the development of galls in the phaeophycean host Nereocystis luetkeana (Mert.) Post. et Rupr. (Apt 1988) and cause texture changes that decrease the commercial value of Undaria (Yoshida \& Akiyama 1979). Also, species of the chlorophycean genus Acrochaete (Correa et al. 1988) have been clearly identified as the cause of massive cell and tissue destruction in the red alga Chondrus crispus Stackh. (Correa \& McLachlan 1994). In this case, experimental infections demonstrated that
A. operculata Correa et Nielsen and A. heteroclada Correa et Nielsen had a negative impact on growth, carrageenan yield, wound healing and regeneration in C. crispus (Correa \& McLachlan 1992). It was also demonstrated that infected thalli were softer and eaten preferentially by crustacean grazers, thereby aggravating the primary negative impact of the endophytic infection (Correa \& McLachlan 1992).

Knowledge of infections involving pigmented algal endophytes is sparse for the western coast of South America; there is only one recent study which reports the presence of Streblonema macrocystis Peters in the sporophylls of Macrocystis pyrifera (L.) C. Agardh off the coast of Valdivia, Chile (Peters 1991). However, it was concluded that $S$. macrocystis does not seem to be a pathogen, as evidence of host damage was not observed.

Recently, as part of a long-term study of algal pathogens affecting the ecologically and economically valuable red alga Iridaea laminarioides, we have detected the presence of at least 2 diseases in wild pop- 
ulations of this host in central and southern Chile. One of them is characterized by the presence of galls developed in close association with infections by an endophytic cyanobacterium (Correa et al. 1993). The other is characterized by an abnormal green pigmentation of the thalli, which become softer when infections are fully developed. Also it has been found that some infected fronds suffer fractures at the lesions due to wave action (Correa pers. obs.). The purpose of this report is to characterize the disease, identify the causing agent and study the events during penetration of the host.

\section{MATERIALS AND METHODS}

A total of 8 localities were visited between March 1991 and December 1992 (Fig. 1). In these localities, Iridaea laminarioides occurred at sites ranging from rocky walls or platforms exposed to direct wave impact, to beaches with large boulders, relatively protected from wave action. In some localities, like Matanzas, Constitución and Pucatrihue, algal populations remain covered with sand during summer and early fall. Fronds of $I$. laminarioides were haphazardly collected at each locality to estimate the frequency of infection at the time of the visit.

For characterization of the disease and isolation of the causing agent, fronds were examined directly in the field and those thalli displaying symptoms of the disease were collected and transported to the laboratory in a cooled container. Characterization of the in-

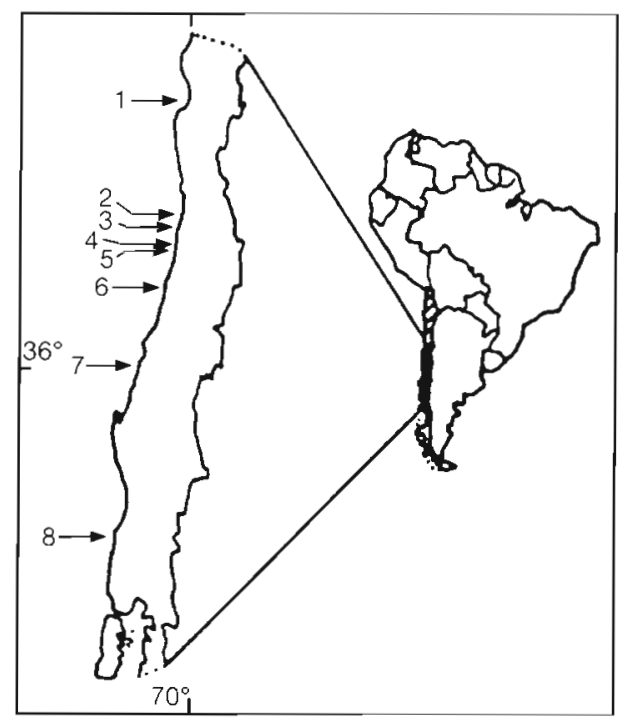

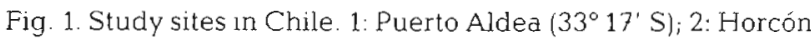

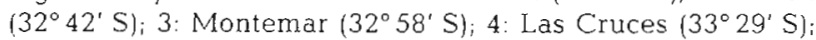
5: Pelancura $\left(33^{\circ} 32^{\prime} \mathrm{S}\right)$; 6 : Matanzas $\left(33^{\circ} 58^{\prime} \mathrm{S}\right)$; 7 : Constitución $\left(35^{\circ} 20^{\prime} \mathrm{S}\right)$; 8: Pucatrihue $\left(40^{\circ} 33^{\prime} \mathrm{S}\right)$ fection was done using whole fronds and sections of live and fixed material

In the laboratory, collected thalli were maintained in aquaria with circulating seawater for 12 to $24 \mathrm{~h}$. Within that period, the material was processed for microscopic observations and the infecting organisms were isolated. Material for light and transmission electron microscope (TEM) analysis was fixed in a glutaraldehyde $(5 \%)$ acrolein $(1 \%)$ mixture in $0.45 \mu \mathrm{m}$ filtered seawater for at least $24 \mathrm{~h}$ (up to $4 \mathrm{~d}$ ) at $4{ }^{\circ} \mathrm{C}$. Postfixation was done in $2 \%$ osmium tetroxide with $1 \%$ potassium ferrocyanide. The latter reagent provided a significant membrane contrast enhancement (Hepler $1980,1981)$. Tissues were infiltrated and embedded in Spurr's (1969) resin and sections were stained with uranyl acetate followed by aqueous lead citrate observations were done in a Philips 300 TEM operated at $60 \mathrm{kV}$ or a Siemens Elmiskop $1 \mathrm{~A}$ operated at $80 \mathrm{kV}$. Material for scanning electron microscope (SEM) was fixed in a mixture of $3 \%$ glutaraldehyde and $1 \%$ formaldehyde in $0.45 \mu \mathrm{m}$ filtered seawater for $24 \mathrm{~h}$, critical-point dried, and coated with a gold-paladium mixture. Observations were made in a JEOL (Mod. JSM-25 S-II) SEM operated at $25 \mathrm{kV}$.

Isolation of the endophytic organisms followed the procedures described for other photosynthetic endophytes (Correa et al. 1988, Correa \& McLachlan 1991). Briefly, fragments of infected tissues were excised from the thalli and their surfaces sterilized by a combination of brushing under running tap water, sonication for 0.5 to 1 min and immersion in 0.5 to $1 \%$ sodium hypochlorite for 15 to $45 \mathrm{~s}$. Slices, $1 \mathrm{~mm}$ thick and with the cortex removed, were obtained from the surfacesterilized fragments. The resulting pieces of tissue were individually incubated in $15 \times 60 \mathrm{~mm}$ glass Petri dishes containing enriched seawater (SFC medium) modified by Correa \& McLachlan (1991) following McLachlan (1982). Growth conditions were $15^{\circ} \mathrm{C}$, 18:6 h L:D cycle and irradiance of 40 to $50 \mu \mathrm{mol} \mathrm{m} \mathrm{m}^{-2} \mathrm{~s}^{-1}$ (standard culture conditions). Endophytic filaments emerging from the infected tissues, or germlings grown from swarmers released by sporangia of the endophyte, developed within $3 \mathrm{wk}$ of incubation. These were removed from the initial cultures with glass needles or Pasteur pipettes and transferred into $60 \times 15 \mathrm{~mm}$ sterile glass Petri dishes with fresh medium. The isolates usually became mature after 1 mo under standard culture conditions. A $1 \mathrm{ml}$ suspension from each isolate was then inoculated into $20 \mathrm{ml}$ test tubes and maintained in triplicate as stock cultures at $10^{\circ} \mathrm{C}$ and $10 \mu \mathrm{mol}$ of photons $\mathrm{m}^{-2} \mathrm{~s}^{-1}$.

For in vitro infections, unialgal sporophytic and gametophytic Iridaea laminarioides were obtained from carpospores and tetraspores released by mature fronds collected at Matanzas. A cleaning protocol as de- 
Table 1. Isolates of Endophyton sp. used for in vitro infections of unialgal Iridaea laminarioides

\begin{tabular}{|lll|}
\hline Locality & Collection date & Isolate \\
\hline Matanzas & May 16, 1991 & M 160591-1 \\
& Aug 25, 1991 & M 250891-1 \\
& Aug 25, 1991 & M 250891-3 \\
& Aug 25, 1991 & M 250891-6 \\
& Aug 25, 1991 & M 250891-9 \\
Horcón & Jun 6, 1991 & H 120691-3 \\
Montemar & Jun 6, 1991 & Mo 120691-4 \\
\hline
\end{tabular}

scribed above was followed with these fronds to ensure the unialgal conditions of laboratory-grown host thalli. Laboratory-cultured thalli, 5 to $15 \mathrm{~mm}$ long, were inoculated with selected isolates (Table 1). These isolates were induced to massive sporulation by changing the culture medium a week prior to host inoculation. After 2 to $3 \mathrm{wk}$ of being in contact with the inoculum, I. laminarioides thalli were brushed, transferred into clean Petri dishes with fresh medium and incubated for an additional 4 wk period under standard culture conditions.

A similar procedure was followed to characterize the events during early in vitro infections. In this case, however, samples for SEM were obtained at 2, 12, 24, 48 and $96 \mathrm{~h}$ after inoculation of host thalli.

\section{RESULTS}

Our survey revealed that the green patch disease is common and affected intertidal populations of Iridaed laminarioides from Puerto Aldea to Pucatrihue. Estimates indicated that the frequency of thalli with fully developed infections (i.e. symptoms detected with the naked eye) ranged from less than $10 \%$ in Pucatrihue (500 fronds examined) to more than $70 \%$ in Matanzas (838 fronds examined). Macroscopically, infected individuals were characterized by the presence of a dark green pigmentation concentrated at the base of the thallus (Fig. 2). Infections commonly appeared as discrete patches of more or less circular contour (Fig. 3). Advanced lesions were characterized by whitish areas of tissue decay (Figs. $2 \& 3$ ).

The green patch disease affected both wild sporophytic and gametophytic fronds of Iridaea laminarioides. A patchy pattern of infection appeared more commonly in gametophytic fronds (Fig. 3), whereas in sporophytic thalli the infections concentrated homogeneously at the basal region (Fig. 2). There was no apparent size-related susceptibility to the disease; infection was detected in fronds 0.2 to $32 \mathrm{~cm}$ long. Advanced lesions and frond decay, however, were more common in fronds larger than $3 \mathrm{~cm}$. Host defor- mations associated with the lesions were rare and occurred when juvenile fronds were infected (Fig. 4).

Microscopically, the infection was characterized by massive replacement of host tissues, mainly the cortex, by an endophytic green alga. In a surface view of infected thalli, endophytic cells displayed a circular to irregular profile up to $13 \mu \mathrm{m}$ in diameter and appeared as isolated units scattered among cortical cells of the host (Fig. 5). Cross-sections through the infected areas showed that these cortical-borne cells were part of a network of invasive filaments which branched profusely into the host. Two different types of endophytic cells were recognized. One was more or less spherical to club-shaped (Fig. 6), measured 12-22 × 10-13 $\mu \mathrm{m}$ and remained embedded in the cortex of the host. Here, 1 or 2 (rarely 3 ) bilenticular pyrenoids were noticed and the parietal chloroplast filled the entire cell. The other type was common in the medulla of the host; cells were cylindrical, $3-4 \times 22-90 \mu \mathrm{m}$, with a parietal chloroplast that usually filled the entire cell when located subcortically (Fig. 7). When growing deeper in the medulla, these filaments became contorted (Fig. 8) and the chloroplast condensed. Here too, 1 or 2 pyrenoids were common although difficult to recognize in cells packed with starch. Cortical-borne endophytic cells developed into sporangia that remained embedded in the cortex of the host (Fig. 9) and carried 8 to 16 (rarely 32 ) spores. Hairs were not found in any of the endophytic cells of the analyzed wild infected fronds.

Damage affected primarily the cortex of Iridaea laminarioides and was due to mechanical disruption of host cells during the development of the invasive filaments. This damage was characterized by compression of host cells (Fig. 10) which displayed a cytoplasm with few structural details, usually limited to a poorly defined plastid. These plastids reacted atypically with the stains, giving 'negative images' (Fig. 11), as compared with plastids of neighbor noncompressed cells or plastids in cells of non-infected tissue (Fig. 12). Furthermore, thylakoids appeared disorganized as the outer double membrane of the plastid disappeared.

Spreading of the endophyte beyond the cortex occurred through the intercellular matrix, although the immediate cell wall was also penetrated (Fig. 13). Little primary destruction was observed in medullary cells, even though there was close contact between host cells and endophytic filaments (Fig. 14).

The release of swarmers by cortex-borne sporangia during reproduction of the endophyte resulted in numerous openings connecting the outside with the inner tissues of the host. These openings seem to facilitate the entry of bacteria (Fig. 15), which colonized the extracellular matrix and invaded and digested previ- 


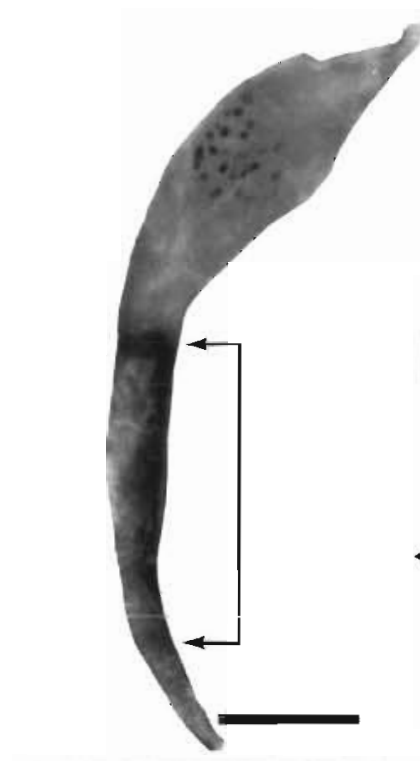

2
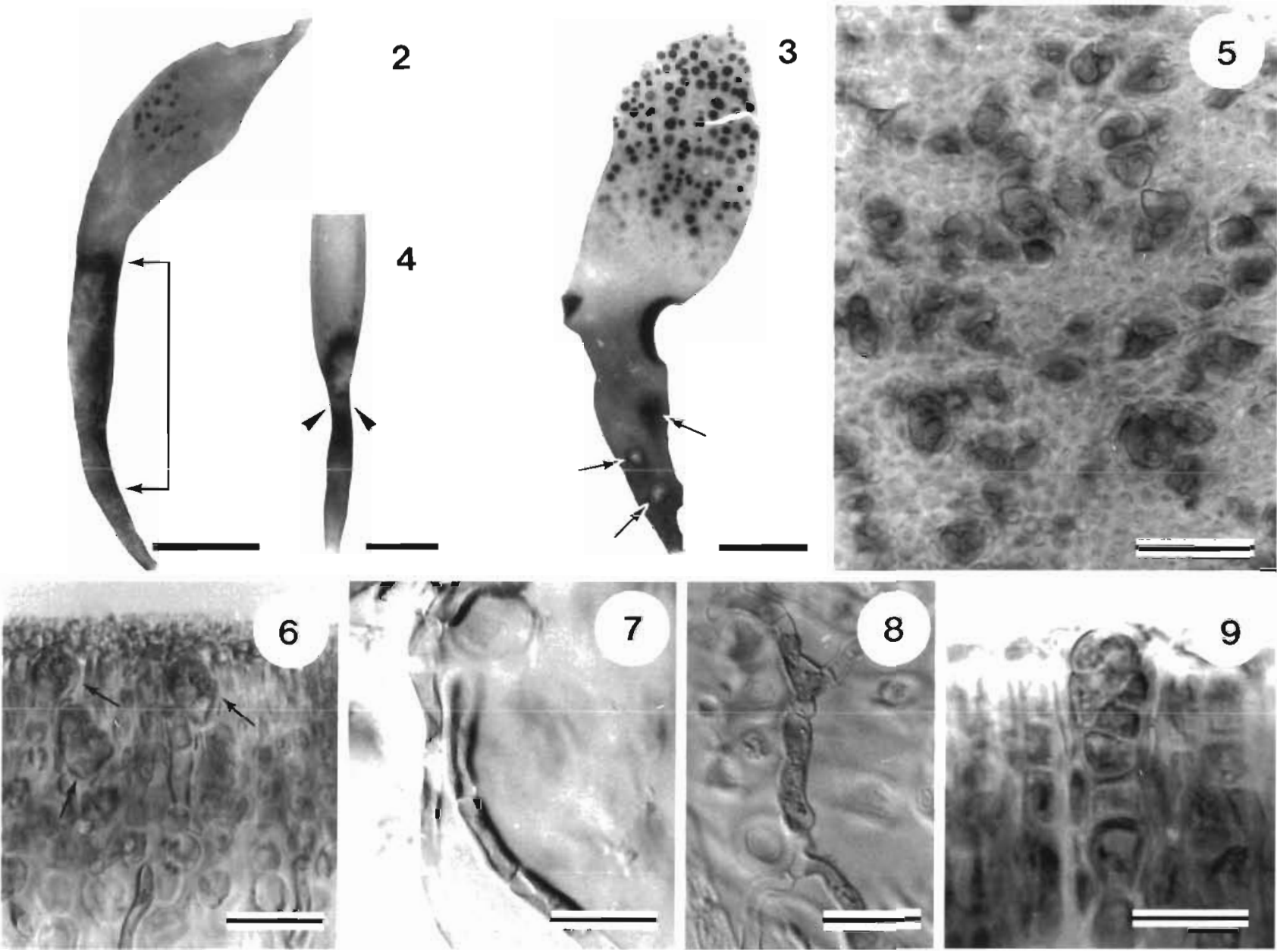

Figs. 2 to 9 . Infected Iridaea laminarioides from nature

Figs. 2 to 4 . Macroscopic aspects of the infection. Fig. 2. Sporophytic frond with an infected, homogeneous dark area (between arrows) at the base of the thallus. Scale bar $=1 \mathrm{~cm}$. Fig. 3. Cystocarpic frond with circular infections (arrows). Decay appears as whitish tissue at the center of the 2 lower lesions. Scale bar $=1 \mathrm{~cm}$. Fig. 4 . Strangulation (arrowheads) of the thallus at the lesion.

Scale bar $=\overline{0.5 \mathrm{~cm}}$

Figs. 5 to 9. Microscopic aspects of the infection. Fig. 5. Surface view of endophytic cells scattered within the host cortex. Scale bar $=50 \mu \mathrm{m}$. Fig. 6. Endophytic cells (arrows) embedded in host cortical tissue. Scale bar $=20 \mu \mathrm{m}$. Fig. 7. Endophytic filament of cylindrical celis located in the outer medulla. Scale bar $=20 \mu \mathrm{m}$. Fig. 8. Contorted, endophytic filament growing deep in the medulla. Scale bar $=20 \mu \mathrm{m}$. Fig. 9 . Mature, cortex-borne sporangium of the endophyte. Scale bar $=10 \mu \mathrm{m}$

Figs. 10 to 19. Ultrastructural aspects of the infection of Iridaea laminarioides by Endophyton sp. Fig. 10. Compressed host cortical cell $(\mathrm{H})$ surrounded by the endophyte (E). Scale bar $=2 \mu \mathrm{m}$. Fig. 11. Cytoplasm disorganization characterized by disappearance of most organelles. Chloroplasts appear disrupted and thylakoids are not enclosed by the external membrane and give negative images. Scale bar $=0.5 \mu \mathrm{m}$. Fig. 12. Cytoplasm of a normal host cell, with a typical rhodophycean plastid (P), mitochondria (arrows) and vacuole (V). Scale bar $=1 \mu \mathrm{m}$. Fig. 13. Penetration of the immediate cell wall (ICW) of a host cell (H) by the endophyte $(E)$. Scale bar $=2 \mu \mathrm{m}$. Fig. 14. Spatial relationship of the endophyte $(E)$ and a medullary host. cell $(\mathrm{H})$. Scale bar $=5 \mu \mathrm{m}$. Fig. 15. Secondary invasion of the host cortex by bacteria. Scale bar $=5 \mu \mathrm{m}$. Fig. 16. Bacteria (B) within a damaged host cell containing only a few subcellular remnants (arrows). The immediate cell wall (ICW), but not the plasmalemma, is still recognizable. Scale bar $=1 \mu \mathrm{m}$. Fig. 17. Surface view of a non-infected region of the thallus. Scale bar $=10 \mu \mathrm{m}$. Fig. 18. Cross-section through the multilamellar cuticle. Scale bar $=1 \mu \mathrm{m}$. Fig. 19. Surface view of an infected area of the thallus. Scale bar $=10 \mu \mathrm{m}$ 

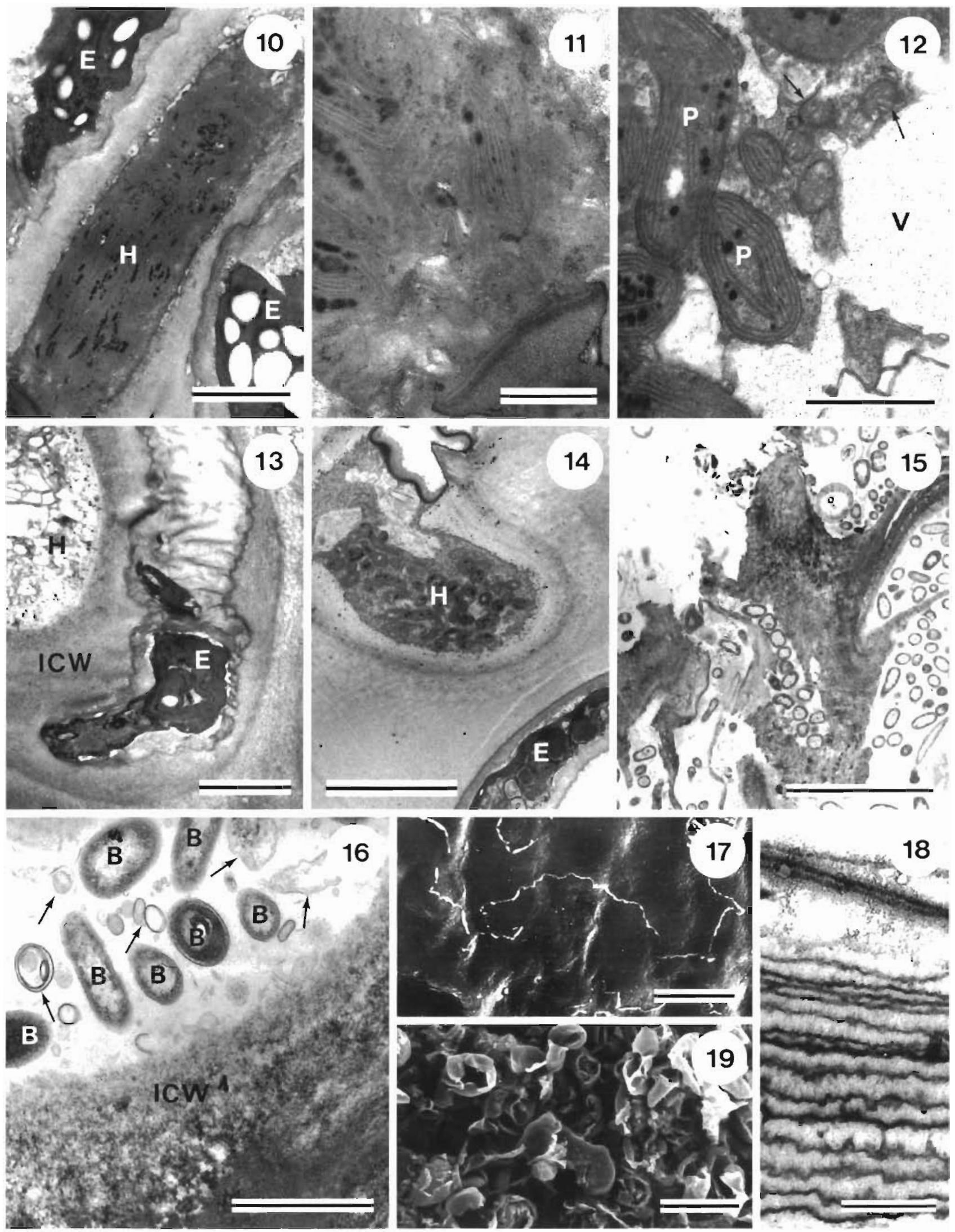
ously damaged host cells (Fig. 16). Invasion of uninfected Iridaea laminarioides tissues by bacteria alone was not observed. With an increased development of secondary bacterial infections, softening of the thallus became apparent.

Changes on the surface of Iridaea laminarioides developed throughout the lesions. The surface of uninfected wild fronds was smooth (Fig, 17) and covered with a multilamellar cuticle (Fig. 18). However, lesions displayed a rough surface (Fig. 19) resulting from the replacement of normal cortical tissue with endophytic cells, so that a protective multilamellar cuticle was absent (Fig. 18).

Unialgal isolates of the endophytic organism were established from most of the visited localities. Differences in general morphology and development among the isolates were not noticed, indicating that only one taxon is involved in the green patch disease of Iridaea laminarioides. Development of the endophyte in unialgal cultures began when obovoid bi- or quadriflagellate spores (Fig. 20), with a single eyespot, settled on the bottom of the culture dishes. Sexual behavior was not detected in swarmers from any of the studied isolates. Flagella were 3 to 4 times longer than the cell and inserted in an anterior papilla (Fig. 20). Spore germination was unipolar (Fig. 21) and in most cases the spore contents migrated immediately into the germination tube (Fig. 21). Branching began at the sporeend (Fig. 22) within $5 \mathrm{~d}$ of germination and in 1 to $2 \mathrm{wk}$ germlings appeared as loosely entangled groups of sparsely branched filaments (Fig. 23). Branching was irregular and plants reached a more or less circular contour, with filaments growing radially from the centre (Fig. 24). Although attachment of the swarmers to the glass substratum occurred prior to germination, germlings and fully developed plants became detached at early stages of development. In general, vegetative cells of the isolated endophyte were cylindrical and measured $4-6.5 \times 20-86 \mu \mathrm{m}$. In apical cells, the chloroplast filled the whole cytoplasm which appeared homogeneously pigmented. Up to 3 pyrenoids were counted in these cells. Intercalary cells, on the other hand, showed a well-defined parietal chloroplast with generally 1 pyrenoid at the centre (Fig. 25).

Maturity of the isolated endophyte was first noticed when intercalary vegetative cells enlarged and issued lateral protuberances (Fig. 26). When maturity was synchronous, all cells in a given plant became sporangial mother cells. Initial differentiation into zoospores was recognized by chloroplast condensation accompanied by cytoplasmic vacuolation in the sporangial mother cell (Fig. 27). Mature sporangia were flaskshaped with a wide base (Fig. 28), L-shaped (Fig. 29), or elongate (Fig. 30). Each sporangium contained 8 to 16 (rarely 32) bi- or quadriflagellate spores which were released individually through an apical aperture. A mucilage plug released prior to the spores was not observed. Whole plants became entangled masses of emptied sporangia (Fig. 31). Germlings from the new generation of spores developed into plants morphologically similar to their parents. Hairs did not develop in actively growing plants or in individuals maintained in stock cultures. In the latter conditions, however, cells within the filaments adopted a spherical shape and appeared as chains of beads (Fig. 32). Formation of an heterotrichous organization did not develop in cultured plants.

All isolates of the endophyte were tested for in vitro infectivity and penetrated successfully sporophytic and gametophytic unialgal Iridaea laminarioides. Infection began wheri swarmers made contact with the surface of the thallus and settled (Fig. 33). Settled swarmers became spheric, 3 to $4 \mu \mathrm{m}$ in diameter, and attached to the host by an adhesive material (Fig. 33). Within $24 \mathrm{~h}$ of inoculation, spores covered the thalli and reached densities of up to 4000 per $\mathrm{mm}^{2}$ (Fig. 34). Germination tubes developed in $3 \mathrm{~d}$ old germlings that either failed to penetrate the outer cell wall of the host thalli (Fig. 35), or successfully broke through it (Fig. 36). Once penetration was achieved, the endophyte grew profusely into the host. The characteristic dark-green pigmentation of wild diseased fronds appeared in laboratory-infected thalli at the end of the experimental period. At this stage, the tissues of sporophytic (Fig. 37) and gametophytic (Fig. 38) I. laminarioides were heavily colonized by the endophyte, whose invasive filaments had reached the medulla. Differences in the development of the infection in sporophytic and gametophytic wild fronds were not apparent in the in vitro infections.

Softening when touched, noticed during laboratory manipulations, and decay were apparent in laboratoryinfected thalli maintained for more than $8 \mathrm{wk}$ under standard culture conditions. At this time, cortex-borne endophytic cells became mature and the released spores germinated and developed into plants identical to those used for host inoculations. Laboratory-infected thalli were completely degraded after 3 to 4 mo in culture. No such signs developed in unialgal, noninfected thalli of the host maintained as controls.

\section{DISCUSSION}

Our study demonstrated that the lesions affecting wild populations of Iridaea laminarioides from Puerto Aldea to Pucatrihue were caused by a green algal endophyte. Causality was established by combining field observations and laboratory experiments, as required to fulfill Koch's postulates (see Andrews \& 

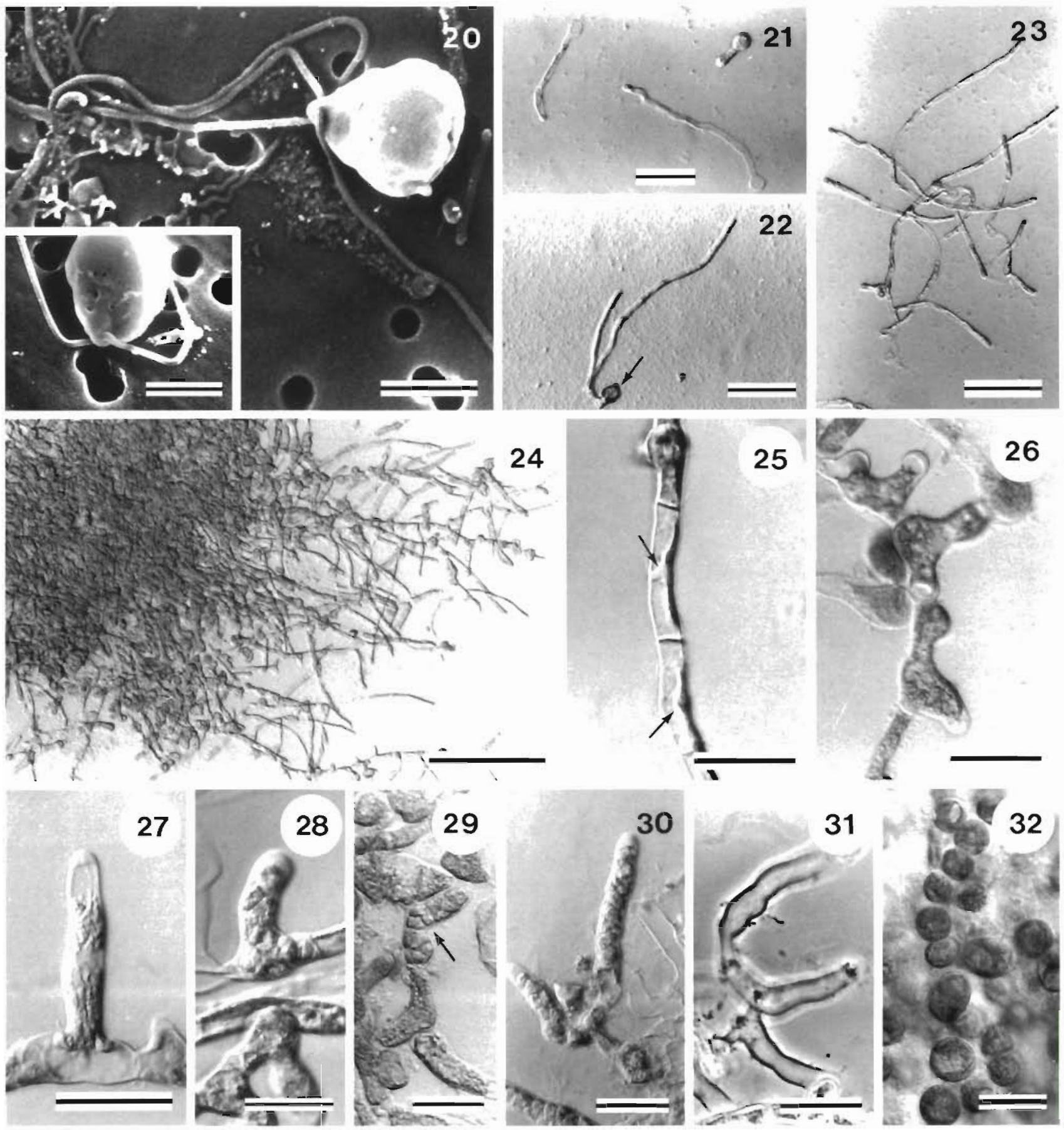

Figs. 20 to 32. Endophyton sp. in unialgal culture. Fig. 20. Quadriflagellate and biflagellate (lower left) zoospores. Scale bar = $5 \mu \mathrm{m}$. Fig. 21. Unipolar germination. Scale bar $=20 \mu \mathrm{m}$. Fig. 22. Initial branching at the spore end (arrow) of the germling. Scale bar $=20 \mu \mathrm{m}$. Fig. 23. $2 \mathrm{wk}$ old germlings. Scale bar $=50 \mu \mathrm{m}$. Fig. 24. Detached, fully developed plant. Scale bar $=100 \mu \mathrm{m}$. Fig. 25. Vegetative filament with intercalary, cylindrical cells containing a parietal chloroplast and a single pyrenoid (arrows). Scale bar $=20 \mu \mathrm{m}$. Fig. 26. Intercalary cells differentiating into sporangial mother cells. Scale bar $=20 \mu \mathrm{m}$. Fig. 27 . Chloroplast condensation at the centre of an elongate sporangial mother cell. Scale bar $=20 \mu \mathrm{m}$. Fig. 28. Intercalary, flask-shaped sporangium. Scale bar $=20 \mu \mathrm{m}$. Fig. 29. Intercalary, L-shape sporangium (arrow). Scale bar $=20 \mu \mathrm{m}$. Fig. 30. Elongate, terminal sporangium. Scale bar $=20 \mu \mathrm{m}$. Fig. 31. Evacuated sporangia. Scale bar $=20 \mu \mathrm{m}$. Fig. 32. Old culture with spherical cells forming a 'chain of beads' structure. Scale bar $=20 \mu \mathrm{m}$ 

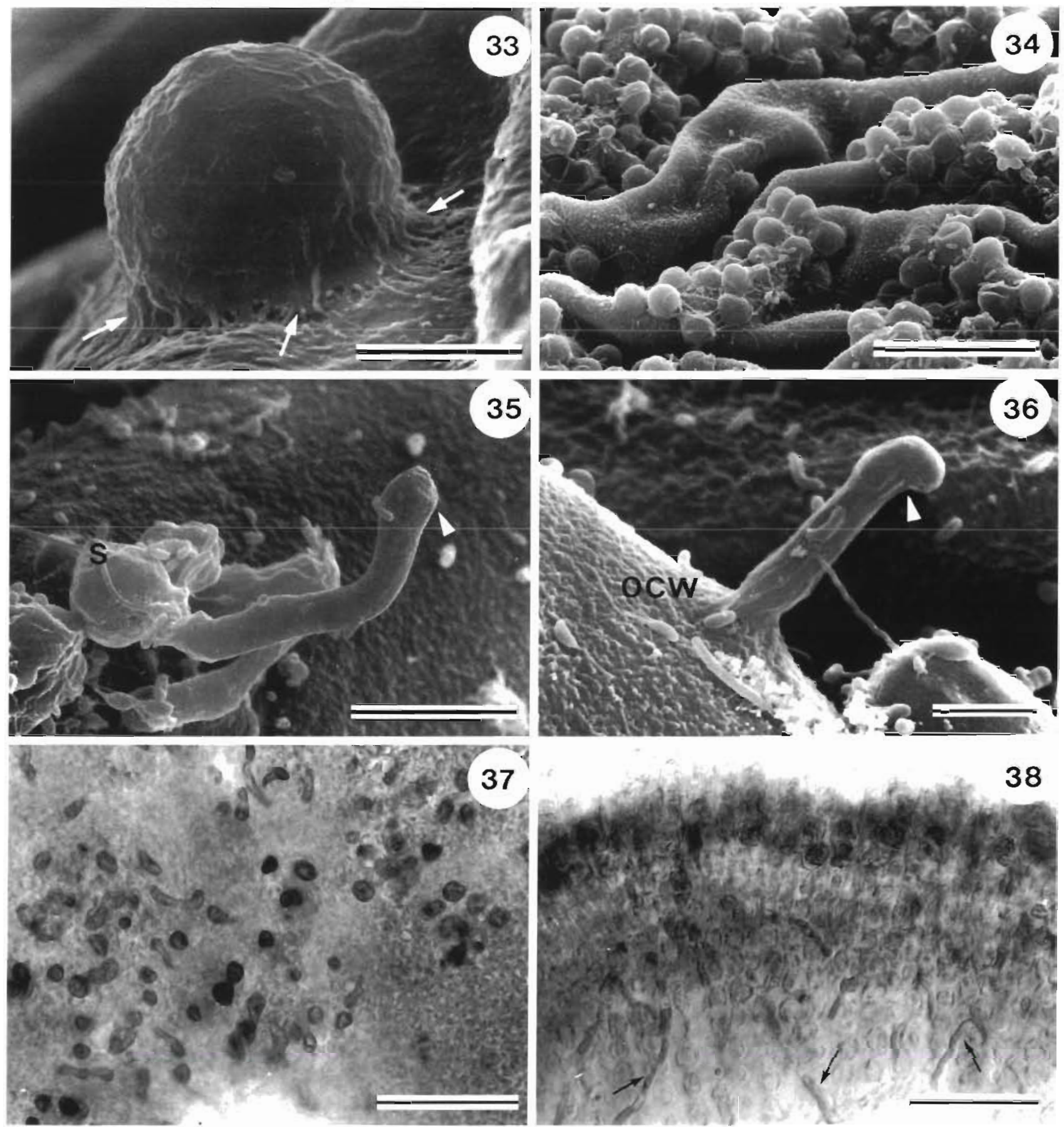

Figs. 33 to 38. In vitro infection of Iridaea laminarioides by Endophyton sp. Fig. 33. Endophyte spore shortly after settling on the surface of the host. Adhesive material is seen at the attachment region (arrows). Scale bar $=2 \mu \mathrm{m}$. Fig. 34 . Representative view of a thallus $24 \mathrm{~h}$ after inoculation. Each sphere represents a single attached spore of the endophyte. Scale bar $=20 \mu \mathrm{m}$. Fig. 35 Endophyte germling with a germination tube (arrowhead) issuing from the spore (S), $3 \mathrm{~d}$ after inoculation. Scale bar $=5 \mu \mathrm{m}$. Fig. 36. Successful penetration. Germination tube (arrowhead) breaking through the host outer cell wall (OCW). Scale bar $=2$ $\mu \mathrm{m}$. Fig. 37. Surface view of a laboratory-infected sporophytic thallus. Scale bar $=50 \mu \mathrm{m}$. Fig. 38 . Cross-section through a laboratory-infected gametophytic thallus. Endophytic filaments (arrows) have reached the medulla of the host. Scale bar $=50 \mu \mathrm{m}$ 
Goff 1985). In this context, the filamentous alga was always found associated with the lesions, it was isolated in unialgal cultures and it infected unialgal hosts in laboratory trials. Furthermore, softening of infected thalli detected in wild fronds with advanced infections also developed in laboratory-infected thalli. Control, non-infected thalli did not develop equivalent symptoms. A number of diseases affect seaweeds and a wide variety of organisms have been found associated with damaged algal hosts (Goff 1983). In very few associations has the etiology been unequivocally demonstrated (reviewed by Correa \& Craigie 1991). Among these cases, only 2 endophytic algae have been recognized as the causing agents of algal lesions. One is the phaeophycean endophyte Streblonema sp., which causes galls in members of the Laminariales (Apt 1988), and the other is Acrochaete operculata, a green endophyte that causes degradative lesions in Chondrus crispus (Correa et al. 1988, Correa \& McLachlan 1994).

Our present study constitutes the second report of an infectious disease affecting Iridaea laminarioides in Chile. The first reported gall developments caused by an endophytic cyanobacterium, which results in severe deformations of the fronds (Correa et al. 1993). In fact, in some localities, like Matanzas, the 2 diseases co-exist. The impact of these diseases, either alone or combined, upon the fronds in nature is not known, although preliminary information indicates that survivorship of diseased fronds is reduced in comparison with uninfected thalli (Correa et al. unpubl.). In this context, there is no information available from other algal pathosystems regarding the effect of the pathogens on wild host populations. It has been suggested that the differential susceptibility of sporophytic fronds to infection by Acrochaete operculata (Correa \& McLachlan 1991), together with a preferential consumption of infected thalli by grazers (Correa \& McLachlan 1992), may play a role in the gametophytic dominance reported for some populations of Chondrus crispus (Bhattacharya 1985). Gametophytic dominance has also been reported in $I$. laminarioides from Pelancura (Hannach \& Santelices 1985) and Matanzas (Santelices \& Norambuena 1987). According to our results it would be difficult to explain gametophytic dominance based on a differential sporophytic susceptibility to Endophyton sp., as both life-history phases seem equally infected. In addition to the potential effect of diseases on wild populations of the ecologically important (Santelices 1990) I. laminarioides, it is necessary to consider the passible effects of pathogens in large-scale farming operations where biomass losses can be severe (Craigie \& Shacklock 1989, Craigie 1990). Although no such Iridaea farms are operating at this moment in Chile, preliminary trials are under way in the south (Otaiza \& Norambuena unpubl.).

The intimate contact between Endophyton sp. and Iridaea laminarioides cells resulted in direct damage to host cells. Pigmented filamentous algae, although common endophytes of numerous algal hosts (e.g. Taylor 1937, Abbott \& Hollemberg 1976, Garbary 1979), have been rarely reported as the primary cause of host cell and tissue damage. For example, species of Streblonema were associated with cortex disruption in Undaria (Yoshida \& Akiyama 1979) and are known to cause abnormal growths in Nereocystis luetkeana (Mert.) Post. et Rupr., Macrocystis integrifolia Bory and Laminaria japonica (Apt 1988). None of these infections, however, resulted in cell destruction or tissue decay. On the contrary, infections by Streblonema sp. triggered hypertrophic and hyperplastic responses in hosts of the Laminariales (Apt 1988), and thickening accompanied by changes in frond texture in Undaria (Yoshida \& Akiyama 1979). Recently, Correa \& McLachlan (1994) demonstrated, for the first time, the occurrence of host cellular damage as a direct result of infections by a pigmented algal endophyte.

Cellular changes in infected Iridaea laminarioides resemble those reported for Chondrus crispus (Correa \& McLachlan 1994). In advanced infections, the plastid loses its envelope and eventually disintegrates. The rest of the cell becomes amorphous and organelles degenerate. Changes include uneven reactivity to electron microscopy stains and negative images of the chloroplasts. Similar changes have also been reported in seaweeds infected by algal parasites (Kugrens \& West 1973, Goff 1976, 1982) and by invasive epiphytes (Rawlence 1972). However, whereas penetrations by parasites and invasive epiphytes are localized and therefore cause minor overall direct host damage, lesions by pigmented algal endophytes cause the decay of relatively large areas of the fronds.

The degradative outcome of the infection by Endophyton sp. is the result of at least 4 successive, related events, which constitute a pattern remarkably similar to that described for infections of Chondrus crispus by Acrochaete operculata (Correa \& McLachlan 1994). The first event involves penetration of the multilamellar host cuticle, a dynamic structure whose periodical removal is considered a defense mechanism to prevent colonization of various algae by other organisms (Sieburth \& Tootle 1981, Moss 1982, Russell \& Veltkamp 1984). This multilamellar structure occurs in species of Iridaea (Gerwick \& Lang 1977, this study) and C. crispus (Gordon \& McCandless 1973, Craigie et al. 1992) but failed to prevent the penetration of these hosts by Endophyton sp. and A. operculata, respectively. The second event is characterized by mechanical damage, which affects host cells during invasion of 
the inner tissues by Endophyton sp., once the host outer cell wall has been breached. Cells of $C$. crispus are also damaged by mechanical means, although it should be noted that $A$. operculata is able to push through host cells, a phenomenon not observed in Endophyton sp. The third event involves the development of Endophyton in the cortex of the host, with concomitant host cell destruction. This pattern of development, shared with $A$. operculata, has 2 important consequences in both $I$. laminarioides and $C$. crispus. One is that the outer cell wall is no longer produced in infected, damaged areas, facilitating the accumulation of normally occurring bacteria at the surface of the thallus. The other consequence is the disruption of the frond surface resulting from swarmers released by cortex-borne sporangia of the endophytes. Finally. the fourth event involves bacterial invasion of the frond through the openings left during release of the swarmers. This latter event accelerates digestion of the thallus in both $C$. crispus and I. laminarioides, and is responsible for the softening observed in advanced infections in diseased wild and laboratory grown fronds of the 2 species. It is important to emphasize that the evidence gathered so far strongly suggests that in C. crispus and I. laminarioides the events indicated above must follow in the right sequence if severe destruction of the thallus is to occur. Supporting this view, Correa \& McLachlan (1992) showed that the contact of bacteria with healthy (i.e. without algal endophytes) medullary tissue of a frond, per se, does not necessarily result in necrosis and softening of the thallus. Furthermore, it is also known that healthy thalli heal wounds, and avoid bacterial infections, by sealing openings that expose inner tissues (Fulcher \& McCully 1969, Azanza-Corrales \& Dawes 1989). This capacity appears diminished or even absent in infections of algal hosts by algal endophytes (Correa \& McLachlan 1992).

Classification of the alga isolated from Iridaea laminarioides as a member of the genus Endophyton Gardner was based upon its vegetative and reproductive features within the host and in unialgal cultures. Endophyton closely resembles the morphology of Entocladia Reinke and Acrochaete Pringsheim. The latter 2 genera, however, are characterized by pseudoparenchymatous development in nature and in unialgal cultures (South 1968, Nielsen 1979, O'Kelly \& Yarish 1981), which is absent in Endophyton (O'Kelly 1982) and in our isolates. Acrochaete operculata, the Atlantic endophyte of Chondrus crispus, is similar to ours in that it does not form a pseudoparenchyma. However, it develops hairs in unialgal cultures and in the host (Correa et al. 1988), a character not found in isolates from I. laminarioides or in Endophyton ramosum isolated from Iridaea flaccida Setchell et Gardner
(O'Kelly 1982). Identity of the endophyte at species level remains to be established. Development within the host and germination and growth in culture suggest a close relationship between our isolates and E. ramosum Gardner (O'Kelly 1982). However, the massive damage caused to the host, a different spatial location of the endophyte in the frond, a higher diversity in sporangial morphology and the absence of sexual reproduction, are some of the features which suggest that ours may be a different species.

Acknowledgements. Funding for this work was provided by grants FONDECYT 751-9 and IFS A 1902-1 to J.A.C. Field and laboratory assistance by M. Cottenie and P. Sánchez is deeply appreciated. We thank J. S. Craigie for the comments on an earlier version of the manuscript. We also appreciate the indepth review and suggestions by 3 anonymous reviewers.

\section{LITERATURE CITED}

Abbott, I. A., Hollemberg, G. J. (1976). Marine algae of California. Stanford University Press, California

Andrews, J. H., Goff, J. L. (1985). Pathology. In: Littler, M. M., Littler, D. S. (eds.) Handbook of phycological methods. Ecological field methods: macroalgae. Cambridge Univer sity Press, Cambridge, p. 573-591

Apt, K. E. (1988). Etiology and development of hiperplasia induced by Streblonema sp. (Phaeophyta) of members of the Laminariales (Phaeophyta). J. Phycol. 24: 28-34

Azanza-Corrales, R., Dawes, C. J. (1989). Wound healing in cultured Eucheuma alvarezii var. tambalang Doty. Bot. Mar. 32: 229-234

Bhattacharya, D. (1985). The demography of fronds of Chondrus crispus Stackhouse. J. exp. mar. Biol. Ecol. 91 $217-231$

Correa, J. A., Craigie, J. S. (1991). Algal pathology. In: García Reina, G., Pedersén, M. (eds.) Proceedings of the COST-48 workshop. Seaweed cellular biotechnology, physiology and intensive cultivation. Universidad de Las Palmas de Gran Canaria, Las Palmas, p. 67-82

Correa, J. A., Flores, V., Sánchez, P. (1993). Deformative disease in Iridaea laminarioides (Rhodophyta): gall development associated with an endophytic cyanobacterium. J. Phycol. 29: 853-860

Correa, J. A., McLachlan, J. L. (1991). Endophytic algae of Chondrus crispus (Rhodophyta). III. Host specifity. J. Phycol. 27: 448-459

Correa, J. A., McLachlan, J. L. (1992). Endophytic algae of Chondrus crispus (Rhodophyta). IV. Effects on the host following infections by Acrochaete operculata and $A$. heteroclada (Chlorophyta). Mar. Ecol. Prog. Ser. 81: 73-87

Correa, J. A., McLachlan, J. L. (1994). Endophytic algae of Chondrus crispus Stackh. (Rhodophyta). V. Fine structure of the infection by Acrochaete operculata (Chlorophyta). Eur. J. Phycol. 29: 33-47

Correa, J. A., Nielsen, R., Grund, D. W. (1988). Endophytic algae of Chondrus crispus (Rhodophyta). II. Acrochaete heteroclada sp. nov., A. operculata sp. nov., and Phaeophila dendroides (Chlorophyta). J. Phycol. 24: 528-539

Craigie, J S. (1990). Irish moss cultivation: some reflections. In: Yarish, C., Penniman, C. A., Van Patten, P. (eds.) Economically important marine plants of the Atlantic. Their biology and cultivation. Connecticut Sea Grant College 
Program, Marine Sciences Institute, University of Connecticut, Groton, p. 37-52

Craigie, J. S., Shachlock, P. F. (1989). Culture of Irish moss. In Boghen, A. D. (ed.) Cold water aquaculture in Atlantic Canada. The Canadian Institute for Research on Regional Development, University of Moncton, Moncton, NB, p. $243-270$

Craigie, J. S., Correa, J A., Gordon, M. E. (1992). Cuticles from Chondrus crispus (Rhodophyta). J. Phycol. 28 $777-786$

Fulcher, R. G., McCully, M. E. (1969). Histological studies on the genus Fucus. IV. Regeneration and adventive embryony, Can. J. Bot. 47: 1643-1649

Gerwick, W., Lang, N. (1977). Structural, chemical and ecological studies on iridescence in Iridaea (Rhodophyta). J. Phycol. 13: 121-127

Garbary, D. (1979). A revised species concept for endophytic and endozoic members of the Acrochaetiaceae (Rhodophyta). Bot. Not. 132: 451-455

Goff, L. J. (1976). The biology of Harveyella mirabilis (Cryptonemiales, Rhodophyceae). V. Host responses to parasite infection. J. Phycol. 12: 313-328

Goff, L. J. (1982). The biology of parasitic red algae. In: Round, F. E., Chapman, D. J. (eds.) Progress in phycological research, Vol. 1. Elsevier, New York, p. 289-369

Goff, L. J (1983). Marine algal interactions: epibiosis, endobiosis, parasitism and disease. In: Tseng, C. K. (ed.) Proceedings of the Joint China-U.S. Phycology Symposium. Science Press, Beijing, p. 221-274

Gordon, E., McCandless, E. L. (1973). Ultrastructure and histochemistry of Chondrus crispus Stackhouse. In: Harvey, M. J., McLachlan, J. (eds.) Chondrus crispus. Nova Scotian Institute of Science, Vol. 27 (Suppl.)., Nova Scotia, p. $111-133$

Hannach, G., Santelices, B. (1985). Ecological differences between the isomorphic reproductive phases of two species of Iridaea (Rhodophyta: Gigartinales). Mar Ecol. Prog. Ser. 22: 291-303

Hepler, P. K. (1980). Membranes in the mitotic apparatus of barley cells. J. Cell Biol. 86: 490-499

Hepler, P. K. (1981). The structure of the endoplasmic reticulum revealed by osmium tetroxide-potassium ferricyanide staining. Eur. J. Cell Biol. 26: 102-110

Kugrens, P., West, J. A. (1973). The ultrastructure of the alloparasitic red alga Choreocolax polysiphoniae. Phycologia 12: $175-186$

McLachlan, J. L. (1982). Inorganic nutrition of marine macroalgae in culture. In: Srivastava, L. M. (ed.) Synthetic and

Responsible Subject Editor: S. Bonotto, Torino, Italy degradative processes in marine macrophytes. Walter de Gruyter, Berlin, p. 71-98

Moss, B. L. (1982). The control of epiphytes by Halidrys siliquosa (L.) Lyngb. (Phaeophyta, Cystoceiraceae). Phycologia 21. 185-191

Nielsen, R. (1979). Culture studies on the type species of Acrochaete, Bolbocoleon and Entocladia (Chaetophoraceae (hlorophycode). Bot. Not. 132: 441-449

O'Kelly, C. J. (1982). Observations on marine Chaetophoracrae (Chlorophyta). III. The structure, reproduction and lite: history of Endophyton ramosum. Phycologia 21. $247-257$

O'Kelly, C. J., Yarish. C. (1981). Observatıons on marine Chaetophoraceae (Chlorophyta). II. On the circumscription of the genus Entocladia Reinke. Phycologia 20: $32-45$

Peters, A. K. (1991). Field and culture studies of Streblonema macrocystis sp. nov. (Ectocarpales, Phaeophyceae) from Chile, a sexual endophyte of giant kelp. J. Phycol 30: $365-377$

Rawlence, D. J. (1972). An ultrastructural study of the relationship between rhizoids of Polysiphonia lanosa (L.) Tandy (Rhodophyceae) and the tissue of Ascophyllum nodosum (L.) Le Jolis (Phaeophyceae). Phycologia 11: $279-290$

Russell, G., Veltkamp, C. J. (1984). Epiphyte survival on skinshedding macrophytes. Mar. Ecol. Prog. Ser. 18: 149-153

Santelices, B. (1990). Patterns of organizations of intertidal and shallow subtidal vegetation in wave exposed habitats of central Chile. Hydrobiologia 192: 35-57

Santelices, B., Norambuena, R. (1987). A harvesting strategy for Iridaed laminarioides in central Chile. Hydrobiologia 151/152: 329-333

Sieburth, J. M., Tootle, J. L. (1981). Seasonality of microbial fouling on Ascophyllum nodosum (L.) Le Jol., Fucus vesiculosus L., Polysiphonia lanosa (L.) Tandy and Chondrus crispus Stackh. J. Phycol 17: 57-64

South, G. R. (1968). Aspects of the development and reproduction of Acrochaete repens and Bolbocoleon piliferum. Can. J. Bot. 26: 101-113

Spurr, A. R. (1969). A low-viscosity epoxy resin embedding medium for electron microscopy. J. Ultrastruct. Res. 26: $31-43$

Taylor, W. R. (1937). Marine algae of the northeastern coast of North America. University of Michigan Press, Ann Arbor

Yoshida, T., Akiyama, K. (1979). Streblonema (Phaeophyta) infection in the frond of cultivated Undaria (Phaeophyceae). Proc. Int. Seaweed Symp. 9:219-223

Manuscript first received: March 15, 1994

Revised version accepted: May 26, 1994 